\begin{tabular}{|} 
Ambiente \& Água - An Interdisciplinary Journal of Applied Science \\
ISSN 1980-993X - doi:10.4136/1980-993X \\
www.ambi-agua.net \\
E-mail: ambi.agua@gmail.com
\end{tabular}

\title{
Variability in phytoplankton community structure and influence on stabilization pond functioning
}

\author{
ARTICLES doi:10.4136/ambi-agua.2507
}

Received: 11 Dec. 2019; Accepted: 19 Feb. 2020

\begin{abstract}
Emmanuel Bezerra D'Alessandro1 ${ }^{(D ;}$; Ina de Souza Nogueira ${ }^{2}{ }^{(D}$; Nora Katia Saavedra del Aguila Hoffmann ${ }^{3 *(D)}$

${ }^{1}$ Departamento de Química. Instituto de Química. Laboratório de Métodos de Extração e Separação. Universidade Federal de Goiás (UFG), Campus Samambaia, Alameda Palmeiras, Chácaras Califórnia, S/N, CEP: 74045-155, Goiânia, GO, Brazil. E-mail: dalessandro.e.b@gmail.com

${ }^{2}$ Departamento de Botânica. Instituto de Ciências Biológicas. Laboratório de Meio Ambiente e Recursos Hídricos. Universidade Federal de Goiás (UFG), Avenida Esperança, S/N, CEP: 74690-900, Campus Samambaia, Goiânia, GO, Brazil. E-mail: ina.nogueira@gmail.com

${ }^{3}$ Departamento de Hidráulica e Saneamento. Programa de Pós-graduação em Engenharia Ambiental e Sanitária. Escola de Engenharia Civil e Ambiental da Universidade Federal de Goiás (EECA-UFG), Avenida Universitária, n 1488, CEP: 74605-220, Quadra 86, Setor Universitário, Goiânia, GO, Brazil

*Corresponding author. E-mail: kasaavedra@ufg.br
\end{abstract}

\begin{abstract}
Density of phytoplankton in stabilization ponds influences treatment performance. The study hypothesized that the phytoplankton community structure varies according to local and temporal changes and consequently influences the treatment of the effluent. Phytoplankton community structure in facultative and maturation ponds in central Brazil was analyzed to provide guidance on system operation and maintenance. Further, species density, abundance, diversity, richness, dominance and beta diversity were measured. The efficiency of the treatment was evaluated based on Biochemical Oxygen Demand (BOD). Additionally, a Canonical Correspondence Analysis (CCA) was used to investigate how physical and chemical variables influenced the composition of the most abundant species in the dry and rainy seasons and the microalgae that were most related to the removal of BOD. One hundred and sixty-eight taxa were recorded, and the most abundant classes in both ponds were Chlorophyceae and Cyanophyceae ( $40 \%$ potentially toxic). The maturation pond had greater adaptability in the rainy season, while the facultative pond was more flexible in the dry season. The best period of growth varied among species. In both ponds, Chlorella minutissima was the one which most contributed to the optimization of the treatment. Thus, identifying phytoplankton species and relating them to water quality parameters and weather can help to understand the ecological dynamics of wastewater treatment and provide useful information for the operation and maintenance of stabilization ponds.
\end{abstract}

Keywords: cyanobacteria, diversity, wastewater.

\section{Variabilidade na estrutura das comunidades fitoplanctônicas e influência no funcionamento de lagoa de estabilização}

\section{RESUMO}

A densidade do fitoplâncton em lagoas de estabilização influencia no desempenho do

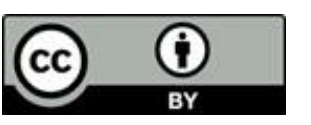

This is an Open Access article distributed under the terms of the Creative Commons Attribution License, which permits unrestricted use, distribution, and reproduction in any medium, provided the original work is properly cited. 
tratamento. A hipótese foi que a estrutura da comunidade fitoplanctônica varia de acordo com as mudanças locais e temporais e, consequentemente, influencia o tratamento do efluente. Foram analisados a estrutura da comunidade fitoplanctônica em lagoas facultativas e de maturação no Brasil central para fornecer orientações sobre a operação e manutenção do sistema. Foram medidas a densidade, abundância, diversidade, riqueza, dominância e diversidade beta das espécies. A eficiência do tratamento foi avaliada com base na Demanda Bioquímica de Oxigênio (DBO). Adicionalmente, foi realizada uma Análise de Correspondência Canônica (CCA) para investigar como variáveis físicas e químicas influenciaram a composição das espécies mais abundantes nas estações seca e chuvosa, e as microalgas mais relacionadas à remoção de DBO. Foram registrados 168 táxons e as classes mais abundantes em ambas as lagoas foram Chlorophyceae e Cyanophyceae (40\% potencialmente tóxicas). A lagoa de maturação possui maior adaptabilidade na estação chuvosa, enquanto a lagoa facultativa foi mais flexível na estação seca. O melhor período de crescimento variou entre as espécies. Em ambas as lagoas, a Chlorella minutissima foi a que mais contribuiu para a otimização do tratamento. Assim, identificar espécies de fitoplâncton e relacioná-las com parâmetros de qualidade da água e a sazonalidade pode ajudar a entender a dinâmica ecológica do tratamento de águas residuais e fornecer informações úteis para a operação e manutenção de lagoas de estabilização.

Palavras-chave: águas residuárias, cianobactéria, diversidade.

\section{INTRODUCTION}

Stabilization ponds are artificial environments used for sewage treatment. An increase in nutrients in these ponds promotes phytoplankton overgrowth, which can risk public health, since some species release toxic substances that can bioaccumulate and cause cancer. Species evenness varies in such ponds; for example, cyanobacteria can dominate in either stabilization or maturation ponds (Aquino et al., 2011).

The efficiency of the stabilization ponds is due to several factors such as temperature, hydraulic retention time, depth, bacteria and algae. In the case of algae in a stabilization pond, algal growth and nutrient assimilation are not only affected by nutrient viability, as they also depend on complex interactions between physical factors such as $\mathrm{pH}$, light intensity, temperature, wind, solar radiation (Von Sperling, 2002) and biotic factors such as algal density (Lau et al., 1995). Phytoplankton in stabilization ponds is essential for oxygen production required for organic matter degradation (Pastich et al., 2016).

The phytoplankton community is involved in many ecosystem processes of inland, estuarine, and marine waters. They also are good bioindicators (Amengual-Morro et al., 2012). Branco et al. (1963) recorded 45 algae genera useful for wastewater treatment, while D'Alessandro et al. (2015) analyzed the efficiency of nutrient removal by algae. However, studies on phytoplankton communities of stabilization ponds are still scarce.

Chlorophyceae is the most speciose algae group in stabilization ponds, usually followed by Euglenophyceae or cyanobacteria (Soldatelli and Schwarzbold, 2012; Gani et al., 2011). Additionally, some species commonly found in environments rich in organic matter also occur in stabilization ponds, such as Chlamydomonas, Euglena, Navicula, Synedra, Oscillatoria, and Phormidium (Sen et al., 2013). Thereby and Granado (2004) recorded Chlorella vulgaris as dominant in the winter and less abundant in other seasons in a stabilization pond. There are plenty of studies on algae and cyanobacteria focusing on limnological variables. However, little is known about how biotic and abiotic variables of stabilization ponds influence the phytoplankton community, despite the importance of algae to the functioning of these ecosystems. 
The hypothesis of the present research was that the structure of the phytoplankton community varies according to local and temporal changes and, consequently, influences the treatment of the effluent. To test this, species density, abundance, diversity, richness, dominance, and beta diversity of the phytoplankton community were analyzed. How physical and chemical variables influenced the composition of the most abundant species in the dry and rainy seasons and the microalgae that were most related to the removal of Biochemical Oxygen Demand (BOD) were also explored. The results helped to identify the microalgae which are better fitted for wastewater treatment in stabilization ponds, and thus provide guidance for system operation and maintenance of the ponds.

\section{MATERIALS AND METHODS}

\subsection{Study sites}

This study was conducted in facultative and maturation pond of the module A of the wastewater treatment plant of Trindade, Goiás, central Brazil $\left(16^{\circ} 39^{\prime} 09^{\prime \prime} \mathrm{S} ; 49^{\circ} 31^{\prime} 50^{\prime \prime} \mathrm{W}\right)$ during six months spanning rainy and dry seasons (September through December 2010, April and May 2011). The plant has an average flow rate of $161.6 \mathrm{~L} \mathrm{~s}^{-1}$, and BOD (biochemical oxygen demand) removal efficiency of $84 \%$. The facultative pond studied has an area of 27,000 $\mathrm{m}^{2}$, depth of $1.25 \mathrm{~m}$, a volume of $33,750 \mathrm{~m}^{3}$, and HRT (hydraulic retention time) of 4.8 days. The maturation pond has an area of $13,975 \mathrm{~m}^{2}, 1.25 \mathrm{~m}$ of depth, volume of $17,468.75 \mathrm{~m}^{3}$, and 2.5 days of HRT.

\subsection{Sampling and species identification}

To choose sampling points, pond depth was first measured using a measuring tape attached to a rigid rod on a boat at points F1, F2, F3, M1, and M2 (Figure 1). In the facultative pond, depth was measured at three-points equidistant to the margin, one at the beginning (F1) at 90 $\mathrm{m}$ from pond entrance, one in the middle $(\mathrm{F} 2)$ at $180 \mathrm{~m}$ from pond entrance, and another at the end of the lagoon (F3) 270 from the entrance. Similarly, depth was measured at two points equidistant to the margin, one at the beginning (M1) $70 \mathrm{~m}$ from the entrance of the maturation pond and another at the end (M2) $150 \mathrm{~m}$ from the entrance.

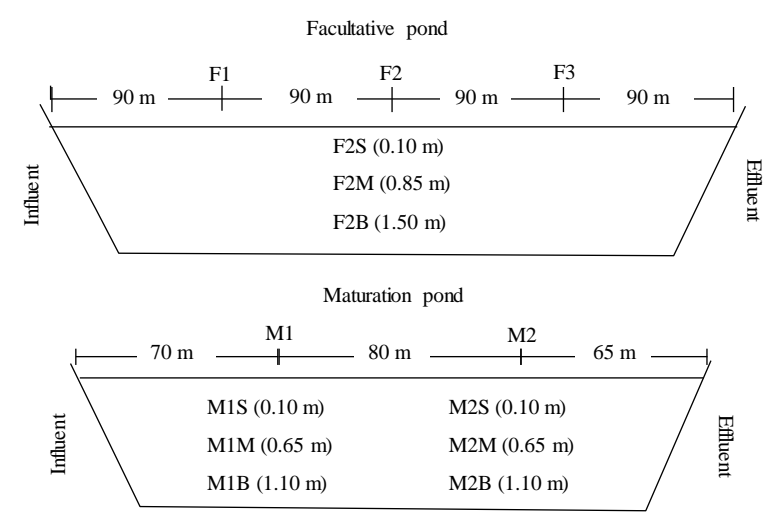

Figure 1. Sampling points in the facultative and maturation ponds of module A of the wastewater treatment plant of Trindade, Goiás, central Brazil. S: surface; M: middle; B: bottom.

Samplings were made using a $5 \mathrm{~L}$ Van Dorn bottle from $09 \mathrm{~h} 40$ to $11 \mathrm{~h} 00$ am in the facultative pond. Using a boat, samplings were collected along the vertical profile at point F2 (surface, middle, and bottom approximately $20 \mathrm{~cm}$ above the mud). In the maturation pond, samplings were made from $10 \mathrm{~h} 50$ to $12 \mathrm{~h} 00 \mathrm{am}$ at points $\mathrm{M} 1$ and $\mathrm{M} 2$ at three depths (surface, 
middle, and bottom) at each point. The maturation pond had two collection points due to the higher concentration of chlorophyll than the facultative pond. The physical, chemical and biological parameters of the maturation pond were obtained by averaging them at two points (M1 and M2) and their depths.

Qualitative samples of phytoplankton were stored in transparent $100 \mathrm{~mL}$ glass bottles and fixed with $4 \%$ formaldehyde. Live samples were also analyzed. Species identification was based on morphological and morphometric characteristics analyzed under an inverted Olympus microscope CKX41, coupled with a camera and a Cell D® program. Nomenclature for classes followed Van Den Hoek et al. (2008); Cyanobacteria was identified using Komárek and Anagnostidis (2005); Chlorophyceae using Komárek and Fott (1983), D’Alessandro and Nogueira (2017); Euglenophyceae Nogueira (2007); for other classes Bicudo and Menezes (2006).

Quantitative samples were placed in $100 \mathrm{~mL}$ amber glass bottles, fixed with Lugol (Bicudo and Menezes, 2006) and analyzed under an inverted microscope Olympus CKX41 using a settling chamber following Utermöhl (1958). Cells were counted in 10 to 15 randomly chosen fields (Uehlinger, 1964). Due to high concentration of organisms, 1:2 and 1:3 dilutions were used. To enhance quantification strategy, were counted a maximum of 250 individuals (unicellular, colonial, coenobium, trichome, and filamentous) of the second most common species. Were adopted a minimum counting efficiency of $97 \%$, which is the probability that the required number of individuals have been counted and new species are less likely to appear (Pappas and Stoermer, 1996). Thus, counting error is less than $20 \%$ at a significance level of $95 \%$. Here, were considered a cell, colony, coenobium colony, trichome, or filament as an individual.

\subsection{Environmental variables}

To calculate the euphotic zone, the Secchi disk value was multiplied by three. Water temperature and dissolved oxygen were measured using an oximeter (Thermo Scientific/Orion 5 stars). Ammonia samples were analyzed by the direct method Nessler following Silva and Oliveira (2001). It was also measured $\mathrm{pH}$ (potentiometric method), conductivity (CND; potentiometric), biochemical oxygen demand (BOD; dilution), chemical oxygen demand (COD; colorimetric), nitrate $\left(\mathrm{NO}_{3} ; \mathrm{UV}\right)$, orthophosphate $\left(\mathrm{PO}_{4}^{-3}\right.$; ascorbic acid), and total phosphorus (TP; ascorbic acid) following APHA et al. (1998).

\subsection{Community structure parameters}

The classification of size fractions for the most abundant species followed Sieburth et al. (1978). Were calculated species diversity using the Shannon (1948) index based on species density, and the evenness index of Pielou (1966). Species richness was measured in each quantitative sample. Abundant species were those with more than $0.8 \%$ abundance at each sampling point. Dominant species in each sampling point were determined following Lobo and Leighton (1986). Were calculated Whittaker's (1972) beta diversity index $\left(\beta_{\mathrm{W}}\right)$ to measure compositional turnover between ponds based on qualitative data.

\subsection{Data analysis}

A Canonical Correspondence Analysis (CCA) was used to test how abiotic variables and seasonality influenced the composition of the most abundant species. The significance of the model was tested using Monte Carlo randomization with 999 runs.

\section{RESULTS AND DISCUSSION}

\subsection{Characteristics of ponds}


Both ponds had working depths of $1.25 \mathrm{~m}$, a higher volume than initially designed, probably because module $\mathrm{C}$ was deactivated. Thus, part of the volume of module $\mathrm{A}$ was directed to other two modules, changing their depths. Also, depth changed considerably during the sampling period, but the average for the maturation and facultative ponds were 1.74 and 1.36 $\mathrm{m}$, respectively. Depth decreased in October (early rainy season) compared to September, likely because one of the pumping stations ("Bruacas") was broken and did not release sewer to the treatment plant, changing flow rate.

The increase in depth in both ponds in November and December 2010 was due to module A's structure, high rainfall, and increased flow rate. The variation in depth of stabilization ponds in the wastewater treatment plant of Parque Atheneu, Goiás, Brazil was related to rainfall and likely illegal release of rainwater to sewage (Martins, 2003). Shammas et al. (2009) point out evaporation of pond water is usually insignificant, except in places with dry and warm weather, such as the study site. The same authors states that evaporation rate varies with temperature, atmospheric pressure, wind speed, and salt content of the water.

The euphotic zone of the stabilization pond varied throughout the sampling period. However, the photic zone of the facultative pond did not vary as much as in the maturation pond, probably due to the pond's size. The greatest depth recorded in both ponds was in November ( $1.85 \mathrm{~m}$ in the facultative, and $1.40 \mathrm{~m}$ in the maturation pond), whereas the deepest euphotic zone was recorded in September $(0.38 \mathrm{~m}$ and $0.17 \mathrm{~m}$, respectively) and the shallowest in November $(0.13 \mathrm{~m}$ and $0.12 \mathrm{~m}$, respectively). However, the facultative pond had the shallowest zone in October, December, April and May.

\subsection{Phytoplankton community structure}

One hundred and sixty-eight taxa were found belonging to six divisions and seven classes (Cyanophyceae, Chlorophyceae, Euglenophyceae, Dinophyceae, Bacillariophyceae, Prasinophyceae, and Cryptophyceae (Figure 2), of which 121 taxa were recorded in the facultative and 152 in the maturation pond. The most speciose class in both ponds was Chlorophyceae, followed by Euglenophyceae and Cyanophyceae. These classes have different life history strategies such as their buoyancy mechanism, which may explain their high diversity and abundance. Previous studies also found dominance of Euglenophyceae instead of Chlorophyceae, due to higher concentration of organic matter (Mahapatra et al., 2013).

The highest phytoplankton density in both ponds was recorded on the surface. This happened in September in the facultative pond $\left(14,076,303\right.$ ind $\left.\mathrm{mL}^{-1}\right)$, while in the maturation pond it was in October $\left(12,462,508\right.$ ind $\left.\mathrm{mL}^{-1}\right)$. Species density increased in the dry season and decreased in the rainy season, due to dilution.

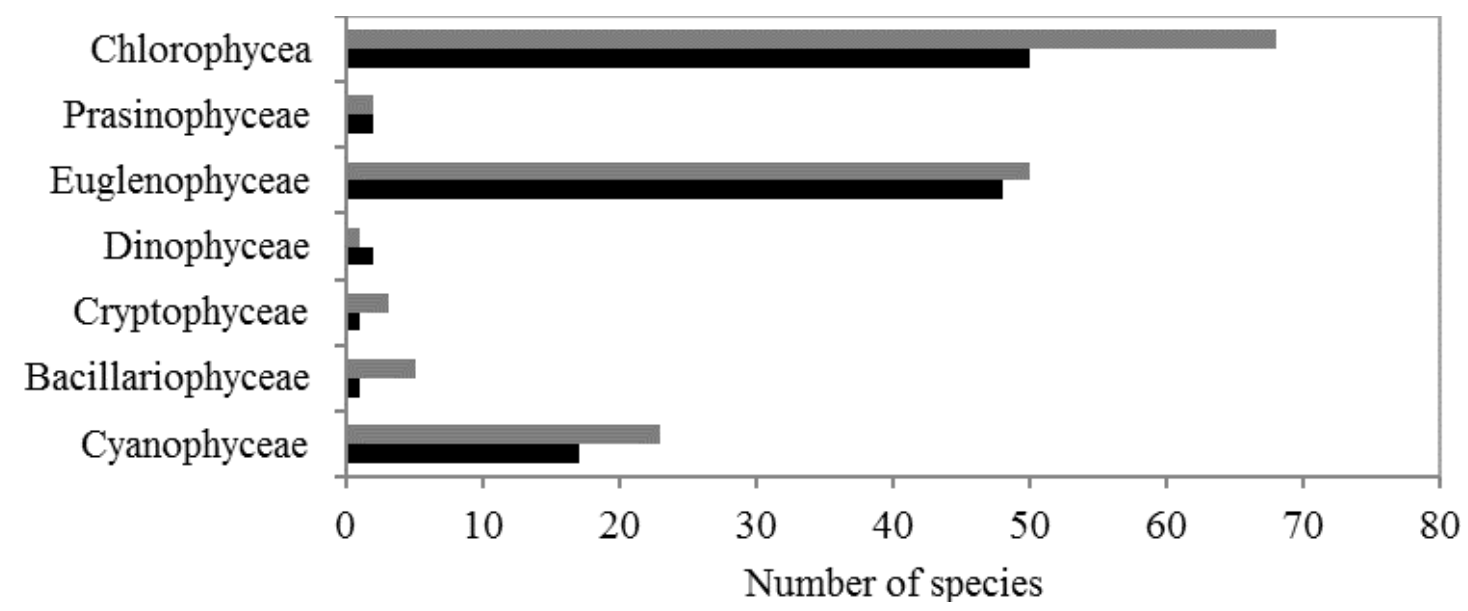


Figure 2. Proportional species richness of phytoplankton per class in the facultative (ם) and maturation $(\square)$ ponds of module A in Trindade wastewater treatment plant, Goiás, central Brazil.

The highest phytoplankton densities ever recorded were observed in the stabilization ponds: $14 \times 10^{6}$ ind $\mathrm{mL}^{-1}$ in the facultative and $12.4 \times 10^{6}$ in the maturation pond. The species densities in wastewater treatment plants were $7 \times 10^{6}$ ind $\mathrm{mL}^{-1}$ in Parque Atheneu, Goiás (Martins, 2003), $9 \times 10^{5} \mathrm{cel} \mathrm{mL}^{-1}$ in Novo Horizonte, São Paulo (Falco, 2005), $3.8 \times 10^{6}$ ind $\mathrm{mL}^{-1}$ in Jacupiranga, São Paulo (Casali, 2008), $5.6 \times 10^{5}$ ind $\mathrm{mL}^{-1}$ in Biossistemas Integrados, Espírito Santo (Delazari-Barroso, 2009), and $4.2 \times 10^{5}$ ind $\mathrm{mL}^{-1}$ in UCS, Rio Grande do Sul (Soldatelli and Schwarzbold, 2012).

The dominant species was Synechocystis sp. (cyanobacteria), which composed on average $75 \%$ of the density in the facultative and $83 \%$ in the maturation pond. Additionally, other algae and cyanobacteria were abundant during the study, such as Chlorella vulgaris, Chlorella minutissima, Closteriopsis acicularis, Merismopedia tenuissima, and Synechococcus sp. (Figure 3). Florentino et al. (2019) evaluation of algal diversity in stabilization pond systems treating domestic wastewater showed that the genera Euglena and Chlorella were present in relatively high frequencies in five of the six effluents analyzed.

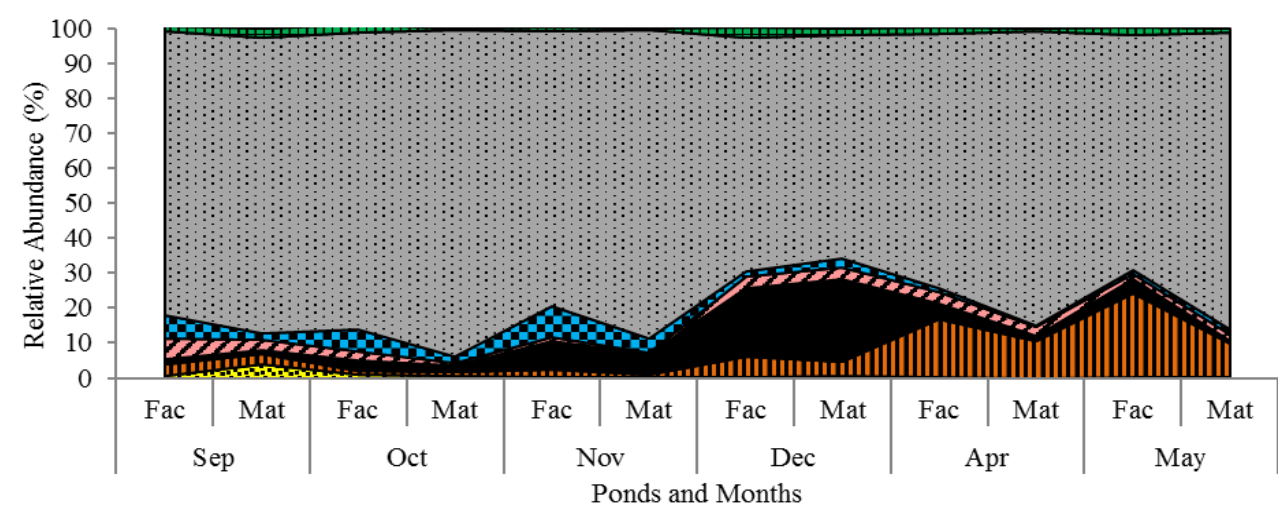

Figure 3. Relative abundance of species with higher density throughout the study, in the facultative and maturation pond of the module A, wastewater treatment plant

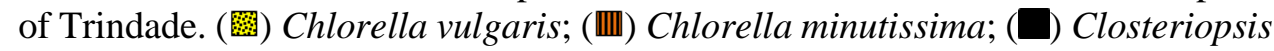
acicularis; (ש) Merismopedia tenuissima; (圆) Synechococcus sp.; (耳) Synechocystis sp.; (䁏) others.

The abundance of Synechocystis sp. decreased in November and December 2010, which allowed the increase in abundance of $C$. acicularis. In April and May 2011, the abundance of C. minutissima increased. Seasonality affected both ponds similarly. The most abundant species were part of the nanoplankton, except for $C$. acicularis, which is microplankton.

The possible cause of the high abundance of these algae and cyanobacteria was their great capacity to reproduce and absorb nutrients in stabilization ponds. Due to these characteristics, the cyanobacteria $M$. tenuissima was one of the most abundant species in the Parque Atheneu Stabilization Ponds, Goiás, BR (Martins, 2003), whereas Planktothrix isothrix as the most abundant in Barbalha, Ceará, BR (Aquino et al., 2011).

A previous study found a high cyanobacteria density in the maturation pond, due to its morphometric parameters and high nutrient availability. A similar situation was found with Synechocystis sp. occurring in a higher abundance in the maturation than in the facultative pond during the whole study, except for December. Cyanobacteria tend to become dominant in turbid water because they are superior competitors at low light intensity, and once their high biomass has created a turbid environment, other phytoplankton species compete less effectively. Eland et al. (2019) determined more variation was seen between the systems waste stabilisation ponds 
than between different stages in the treatment processes for both eukaryotic and cyanobacterial communities. Chlorella species and Planktophrix cyanobacteria dominated both treatment systems.

Species diversity, evenness, richness, and dominance were, on average, higher in the rainy than in the dry season in the facultative pond. The opposite pattern was observed in the maturation pond, probably due to differences in pond structure. Species diversity increased from October to December in both ponds, probably due to increased rainfall, which carried particles of suspended solids into the pond, reducing the euphotic zone and decreasing dissolved oxygen concentration, favoring new species, especially flagellates (Riediger et al., 2015), such as Chlamydomonas sp., Chilomonas sp., Chlorogonium sp., and Collodictyon sp. because, these species are heterotrophic and do not need light to produce metabolites. These heterotrophic algae have high potential to reduce cyanobacterial blooms (Kobayashi, 2013).

The most speciose division in stabilization ponds is usually Chlorophyte, being Chlorella the most abundant genus. Chlorella is a microalgae widely used in industry, mainly for the production of biodiesel, polyunsaturated fatty acids (PUFAS), omega-3, lutein and other antioxidants. Therefore, the effluent from the stabilization ponds of our study site can be used as a nutrient medium for cultivating Chlorella, making the production of bioproducts viable (Abdel-Raouf et al., 2012), as implemented by other studies (Dahmani et al., 2016). The most common cyanobacteria genera in stabilization ponds are Oscillatoria and Microcystis, and common algae are Chlamydomonas, Euglena, Chlorella, Scenedesmus, and Micractinium. These algae were recorded in our study site and could potentially be used in biotechnological applications.

The genera Aphanocapsa, Phormidium, Planktothrix, Pseudanabaena, Synechocystis, and Synechococcus recorded in the study site are considered potentially toxic. Merismopedia tenuissima can also produce cyanotoxins of microcystin type. However, cyanobacteria are not only ones to produce toxins, the algae Euglena granulata, E. clavata and E. anabaena found in the study site can produce toxins (Zimba et al., 2017).

Beta-diversity $\left(\beta_{\mathrm{W}}\right)$ describes the turnover or change in species identities along space. It is a measure of difference in species composition between local communities. Thereby, $\beta_{\mathrm{W}}$ in the facultative pond was high in September (20.7) and low in October (12), whereas it was high in April (20.2) and lower in October (8.6) in the maturation pond. Both ponds had relatively low $\beta_{\mathrm{w}}$, indicating a low turnover in the phytoplankton community, i.e., ponds have high similarity (Schuster et al., 2015) and environments with high productivity can present low $\beta \mathrm{w}$ (ZorzalAlmeida et al., 2017). The maturation pond had higher $\beta_{\mathrm{W}}$ in the rainy season, whereas it was higher in the dry season in the facultative pond. Increase $\beta_{\mathrm{W}}$ in the maturation pond (Nov. Apr.) was mainly due to Chlorophyceae phytoflagellates, such as Chlamydomonas and Chlorogonium.

\subsection{Species-environment relationship}

The most frequent species could be divided into four groups regarding their response to environmental variables. Species of Group I occurred in September (end of the dry season), Group II in October (late dry and early rainy season), Group III in November and December (mid rainy), and Group IV in April (late rainy and early dry season) and May (early dry). $C$. minutissima had higher relationship in Group IV, while C. acicularis in Group III and the remaining species in Groups I and II (Figure 4a). The variables most correlated with Axis 1 were HRT and temperature, whereas BOD, CND, and ammonia were most correlated with Axis 2. Correlations between Monte Carlo parameters were higher than 0.98 for Axes 1 and 2 for both ponds (Table 1), i.e., there is not only a single dominant variable that determines the relationship between species and environment. 
The analysis showed the same groups for the maturation pond (Figure $4 \mathrm{~b}$ ). The variables most correlated with Axis 1 were ammonia, temperature, euphotic zone, and HRT, while COD, DO, CND, and euphotic zone were most correlated with Axis 2 (Table 1).
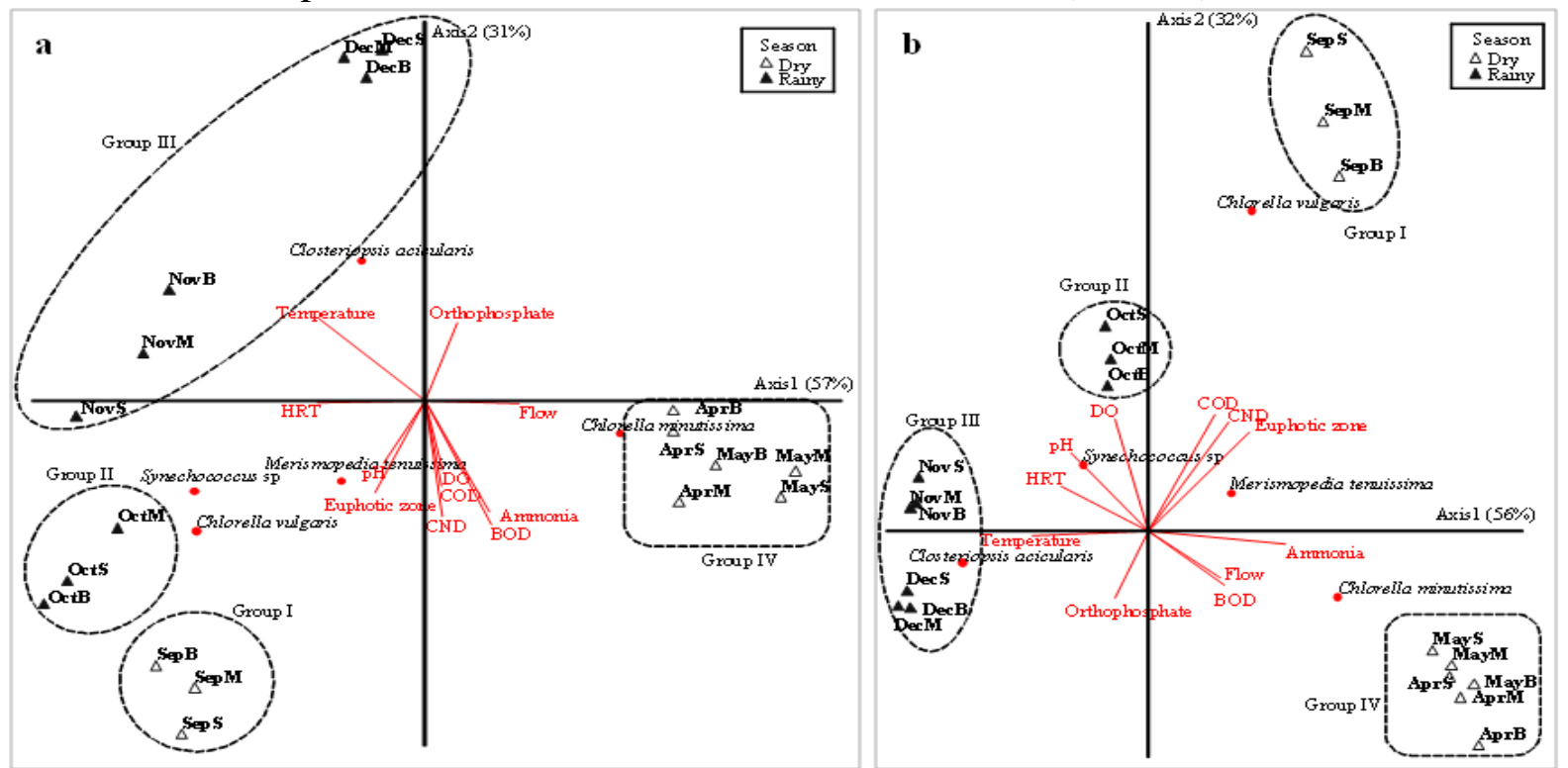

Figure 4. Ordination diagram showing the result of CCA for the relationship between species composition and environmental variables measured in the facultative (a) and maturation (b) pond. For legend see material and methods.

Table 1. Summary table of showing the results of CCA. Loadings, relative eigenvalues, and $p$ value for the model obtained with Monte Carlo randomizations in the facultative and maturation pond.

\begin{tabular}{|c|c|c|c|c|}
\hline & \multicolumn{2}{|c|}{ Facultative Pond } & \multicolumn{2}{|c|}{ Maturation Pond } \\
\hline & Axis 1 & Axis 2 & Axis 1 & Axis 2 \\
\hline \multicolumn{5}{|l|}{ Explicability } \\
\hline Eigenvalues & 0.38 & 0.21 & 0.42 & 0.24 \\
\hline$\%$ of Variance & 57 & 31 & 56 & 32 \\
\hline Corr. of Variables & Eigenvectors & Eigenvectors & Eigenvectors & Eigenvectors \\
\hline DO & 0.11 & -0.42 & -0.23 & $0.76^{*}$ \\
\hline Temp. & $-0.63^{*}$ & 0.50 & $-0.80^{*}$ & -0.03 \\
\hline $\mathrm{pH}$ & -0.25 & -0.38 & -0.53 & 0.53 \\
\hline CND & 0.11 & $-0.71^{*}$ & 0.56 & $0.75^{*}$ \\
\hline COD & 0.10 & -0.53 & 0.46 & $0.80^{*}$ \\
\hline Orthophosphate & 0.19 & 0.48 & -0.23 & -0.47 \\
\hline Ammonia & 0.39 & $-0.69^{*}$ & $0.94^{*}$ & -0.09 \\
\hline Flow & 0.56 & -0.02 & 0.50 & -0.33 \\
\hline HRT & $-0.64^{*}$ & -0.01 & $-0.60^{*}$ & 0.31 \\
\hline BOD & 0.40 & $-0.76^{*}$ & 0.53 & -0.37 \\
\hline Euphotic zone & -0.29 & -0.57 & $0.70^{*}$ & $0.68^{*}$ \\
\hline Sp $x$ Environ ${ }^{\mathrm{a}}$ & 0.995 & 0.987 & 0.999 & 0.990 \\
\hline
\end{tabular}

*correlation coefficients important for axes building.

${ }^{a}$ Monte Carlos Correlation, Species x Environmental $(p=0.001)$.

The density of the most abundant species varied seasonally. Previous studies (Reynolds, 2006) also found a seasonal variation in species abundance of algae that track environmental change throughout the year. In this same study, Chlorella was tolerant to stratification and sensitive to low nutrient concentration. Species dominance patterns can change throughout the 
day according to changes in physical and chemical variables (Bernal et al., 2008). In the facultative pond, $C$. vulgaris occurred in October and September when stratification was more pronounced and the euphotic zone was greater. In both ponds, $C$. minutissima was better adapted to the dry season, higher concentrations of ammonia and BOD, and smaller HRT. Thus, this species may be promising to be used in wastewater treatment, due to its high rate of nutrient uptake. Also, this species was less affected by euphotic zone than $M$. tenuissima, showing that the latter can be heterotrophic or mixotrophic, while M. tenuissima is autotrophic.

Species of the genus Synechococcus prefer homogeneous habitats, are sensitive to low light, dependent on the autotrophic system. High rainfalls tend to homogenize ponds. Thus, the abundance of Synechococcus sp. was predicted by October (early rainy season) and euphotic zone. On the other hand, Merismopedia prefer high ammonia concentration. Consequently, $M$. tenuissima was more affected by ammonia in our study. Generally, cyanobacterial blooms can be avoided by decreasing the phosphorus concentration at the site (Fastner et al., 2016). In this study the cyanobacteria were more influenced by the euphotic zone. Thus, to avoid cyanobacterial blooms in stabilization ponds, this variable must also be taken into account and not only the concentration of phosphorus.

C. acicularis was more abundant in the months of high rainfall, possibly due to the increase of temperature, HRT and dilution of toxic substances of the sewage (e.g., ammonium and metals), which can influence phytoplankton growth (Reynolds, 2006).

Therefore, environmental variables influence phytoplankton species distribution, diversity, abundance, and density in stabilization ponds, which can affect treatment efficiency.

Species of the genus Synechococcus prefer homogeneous habitats, are sensitive to low light, dependent on the autotrophic system. High rainfalls tend to homogenize ponds. Thus, the abundance of Synechococcus sp. was predicted by October (early rainy season) and the euphotic zone. On the other hand, Merismopedia prefer high ammonia concentration. Consequently, $M$. tenuissima was more affected by ammonia in our study. Generally, cyanobacterial blooms can be avoided by decreasing the phosphorus concentration in the site (Fastner et al., 2016). In this study, the cyanobacteria were more influenced by the euphotic zone. Thus, to avoid cyanobacterial blooms in stabilization ponds, this variable must also be taken into account and not only the concentration of phosphorus.

\section{CONCLUSION}

In conclusion, our study showed that stabilization ponds had low alpha- and beta diversity, despite having 168 taxa. However, beta diversity was higher in the rainy season in the maturation pond and in the dry season in the facultative pond. About $40 \%$ of the cyanobacteria recorded are potentially toxic. Thus, not only cyanobacteria, but also cyanotoxins launched in the ponds after treatment should be quantified. Except for $C$. acicularis, the most abundant cyanobacteria and algae in the ponds were nanoplankton, with $C$. minutissima the most important species for sewage treatment. This species has a high growth rate, higher contact surface of the cell, and mixotrophy and/or heterotrophy. Thus, identifying phytoplankton species and relating them to water quality parameters and weather can help to understand the ecological dynamics of wastewater treatment and provide useful information for the operation and maintenance of stabilization ponds.

\section{REFERENCES}

ABDEL-RAOUF, N.; AL-HOMAIDAN, A. A.; IBRAHEEM, I. B. M. Microalgae and wastewater treatment. Saudi Journal Biological Sciences, v. 19, p 257-275, 2012. https://dx.doi.org/10.1016/j.sjbs.2012.04.005 
AMENGUAL-MORRO, C.; MOYÀ NIELL, G.; MARTÍNEZ-TABERNER, A. Phytoplankton as bioindicator for waste stabilization ponds. Journal of Environmental Management, v. 95, p. S71-S76, 2012. https://dx.doi.org/10.1016/j.jenvman.2011.07.008

APHA; AWWA; WEF. Standard Methods for the Examination of Water and Wastewater. 20. ed. Washington, 1998.

AQUINO, E. P.; OLIVEIRA, E. C. C.; FERNANDES, U. L.; LACERDA, S. R. Fitoplâncton de uma Lagoa de Estabilização no Nordeste do Brasil. Brazilian Journal of Aquatic Science Technology, v. 15, p. 71-77, 2011. https://dx.doi.org/10.14210/bjast.v15n1.p7177

BERNAL, C. B.; VÁZQUEZ, G.; QUINTAL, I. B.; BUSSY, A. L. Microalgal dynamics in batch reactors for municipal wastewater treatment containing dairy sewage water. Water Air \& Soil Pollution, v. 190, p. 259-270, 2008. https://dx.doi.org/10.1007/s11270-0079598-3

BICUDO, C. E. M.; MENEZES, M. Gênero de algas de águas continentais do Brasil. São Carlos: Rima, 2006.

BRANCO, S. M.; BRANCO, W. C.; LIMA, H. A. S.; MARTINS, M. T. Identificação e importância dos principais gêneros de algas de interesse para o tratamento de águas e esgotos. São Carlos, 1963.

CASALI, S. P. Variabilidade temporal da comunidade fitoplanctônica em lagoas facultativas de dois sistemas de tratamento de esgotos com diferentes configurações (Baixo Ribeira de Iguape, SP). 2008. Dissertação (Mestrado em Hidráulica e Saneamento) - Universidade de São Paulo, São Carlos, 2008.

D'ALESSANDRO, E. B.; SAAVEDRA, N. K.; SANTIAGO, M. F.; D’ALESSANDRO, N. C. O. Influence of seasonality in stabilization ponds. Ingeniería del agua, v. 19, p. 193209, 2015. https://dx.doi.org/10.4995/ia.2015.3418

D'ALESSANDRO, E. B.; NOGUEIRA, I. D. E. S. Algas planctônicas flageladas e cocoides verdes de um lago no Parque Beija-Flor, Goiânia, GO, Brasil. Hoehnea, v. 44, p. 415430, 2017. https://dx.doi.org/10.1590/2236-8906-84/2016

DAHMANI, S.; ZERROUKI, D.; RAMANNA, L. Cultivation of Chlorella pyrenoidosa in outdoor open raceway pond using domestic wastewater as medium in arid desert region. $\begin{array}{llllll}\text { Bioresource } & \text { Technology, } & \text { v. } & 219, & \text { p. }\end{array}$ https://dx.doi.org/10.1016/j.biortech.2016.08.019

DELAZARI-BARROSO, A.; OLIVEIRA, F. F.; MARQUES, M. A. M. Avaliação temporal do fitoplâncton na lagoa de polimento de uma estação de tratamento de esgoto do tipo biossistemas integrados, em Alto Caxixe, Venda Nova do Imigrante, ES, Brasil. Revista Científica Faesa, v. 5, p. 7-16, 2009.

ELAND, L. E.; DAVENPORT, R. J.; SANTOS, A. B.; MOTA FILHO, C. R. Molecular evaluation of microalgal communities in full-scale waste stabilization ponds.

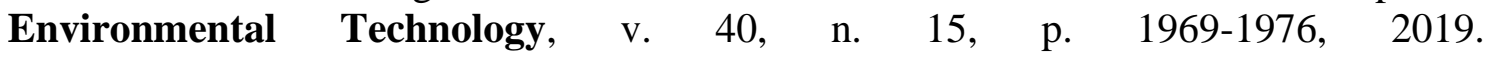
https://doi.org/10.1080/09593330.2018.1435730

FALCO, P. B. Estrutura da comunidade microbiana (algas e bactérias) em um sistema de lagoas de estabilização em duas escalas temporais: nictemeral e sazonal. 2005. Tese (Doutorado em Hidráulica e Saneamento) - Universidade de São Paulo, São Carlos, 2005. 
FASTNER, J.; ABELLA, S.; LITT, A. Combating cyanobacterial proliferation by avoiding or treating inflows with high P load-experiences from eight case studies. Aquatic Ecology, v. 50, p. 367-383, 2016. https://dx.doi.org/10.1007/s10452-015-9558-8

FLORENTINO, A. P. et al. Identification of microalgae from waste stabilization ponds and evaluation of electroflotation by alternate current for simultaneous biomass separation and cell disruption. Engenharia Sanitária e Ambiental, v. 24, n. 1, p. 177-186, 2019.

GANI, M. A.; ALFASANE, M. A.; KHONDKER, M. Limnology of wastewater treatment lagoons at Pagla, Narayanganj. Bangladesh Journal Botany, v. 40, p. 35-40, 2011. https://dx.doi.org/10.3329/bjb.v40i1.7995

GRANADO, D. C. Variação nictemerais e sazonais na estrutura da comunidade fitoplanctônica num sistema de lagoas de estabilização (Novo Horizonte). 2004. Dissertação (Mestrado em Hidráulica e Saneamento) - Universidade de São Paulo, São Carlos, 2004.

KOBAYASHI, Y.; HODOKI, Y.; OHBAYASHI, K. Grazing impact on the cyanobacterium Microcystis aeruginosa by the heterotrophic flagellate Collodictyon triciliatum in an

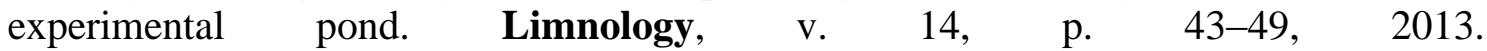
https://dx.doi.org/10.1007/s10201-012-0384-6

KOMÁREK, J.; ANAGNOSTIDIS, K. Cyanoprokaryota 2. Teil: Oscillatoriales. In: BÜDEL, B.; KRIENITZ, L.; GÄRTNER, G.; SCHAGERL, M. (eds.). Sübwasserflora von Mitteleuropa. Munique: Elsevier Spektrum Akademischer Verlag, 2005.

KOMÁREK, J.; FOTT, B. Chorophyceae (Grünalgen), Ordiniung: Chlorococcales. In: HUBER-PESTALOZZI, G. (ed.). Das Phytoplankton des Süsswaser: Systematik und Biologie. Stuttgart: E. Schwiezerbat'sche Verlagsbuch - handlung, 1983.

LAU, P. S.; TAM, N. F. Y.; WONG, Y. S. Effect of Algal Density on Nutrient Removal from Primary Settled Wastewater. Environmental Pollution, v. 89, n. 1, p. 59-66, 1995. https://dx.doi.org/10.1016/0269-7491(94)00044-E

LOBO, E.; LEIGHTON, G. Estructuras comunitarias de las fitocenosis planctónicas de los sistemas de desembocaduras de ríos y esteros de la zona central de Chile. Revista de Biología Marina y Oceanografia, v. 22, p. 1-29, 1986.

MAHAPATRA, D. M.; CHANAKYA, H. N.; RAMACHANDRA, T. V. Treatment efficacy of algae-based sewage treatment plants. Environmental Monitoring and Assessment, v. 185, p. 7145-7164, 2013. https://dx.doi.org/10.1007/s10661-013-3090-x

MARTINS, N. R. Dinâmica de algas e aspectos limnológicos em um sistema de lagoas de estabilização de esgotos sanitários em Goiânia-Goiás. 2003. Dissertação (Mestrado) Instituto de Ciências Biológicas, Univerdidade Federal de Goiás, Goiânia, 2003.

NOGUEIRA, I. de S. Biodiversidade de algas planctônicas dos corpos hídricos artificiais do parque Beija-Flor, Município de Goiânia, Goiás: Cyanobacterias, Bacillariophyceae, Euglenophyceae e Chlorophyceae. 2007. Trabalho de Conclusão de Curso (Graduação) - Universidade Federal de Goiás. Goiânia, 2007.

PAPPAS, J. L.; STOERMER, E. Quantitative method for determining a representative algal sample count. Journal of Phycology, v. 32, p. 693-696, 1996. https://dx.doi.org/10.1111/j.0022-3646.1996.00693.x

PASTICH, E. A.; GAVAZZA, S.; CASÉ, M. C. C.; FLORENCIO, L.; KATO, M. T. Structure and dynamics of the phytoplankton community within a maturation pond in a semiarid region. Brazilian Journal of Biology, v. 76, n. 1, p. 144-153, 2016. 
http://dx.doi.org/10.1590/1519-6984.15214

PIELOU, E. C. Shannon's Formula as a Measure of Specific Diversity: Its Use and Misuse on JSTOR. American Naturalist, v. 100, p. 463-465, 1966.

REYNOLDS, C. S. The Ecology of Phytoplankton. New York: Cambridge University Press, 2006.

RIEDIGER, W.; BUENO, N. C.; SEBASTIEN, N. Y. Spatial and temporal variation of phytoplankton in subtropical stabilization ponds. Acta Limnologica Brasiliensa, v. 27 , p. 441-453, 2015. https://dx.doi.org/10.1590/S2179-975X2715

SHAMMAS, N. K.; WANG, L. K.; WU, Z. Waste Stabilization Ponds and Lagoons. In: WANG, L. K.; PEREIRA, N. C.; HUNG, Y. T. (eds). Handbook of Environmental Engineering: Biological Treatment Processes. Totowa: Humana Press, 2009. p. 315-370.

SHANNON, C. E. A Mathematical Theory of Communication. The Bell System Technical Journal, v. 27, p. 379-423, 1948. https://dx.doi.org/10.1002/j.15387305.1948.tb01338.x

SILVA, A. S.; OLIVEIRA, R. D. Manual de análises físico-químicas de águas de abastecimento e residuárias. Campina Grande: DEC/CCT/UFPG, 2001.

SEN, B.; TAHIR, M.; SONMEZ, F. Relationship of Algae to Water Pollution and Waste Water Treatment. In: ELSHORBAGY, W.; CHOWDHURY, R. K. (eds.). Water Treatment. Rijeka: InTech, 2013. p. 335-354.

SCHUSTER, K. F.; TREMARIN, P. I.; SOUZA-FRANCO, G. M. De. Alpha and beta diversity of phytoplankton in two subtropical eutrophic streams in southern Brazil. Acta Botanica Brasilica, v. 29, p. 597-607, 2015. https://dx.doi.org/10.1590/0102-33062015abb0060

SIEBURTH, J.; SMETACEK, V.; LENZ, J. Pelagic ecosystem structure: Heterotrophic compartments of the plankton and their relationship to plankton size fractions. Limnology Oceanography, v. 23, p. 1256-1263, 1978. https://dx.doi.org/10.4319/lo.1978.23.6.1256

SOLDATELLI, V. F.; SCHWARZBOLD, A. Phytoplankton community in maturation lakes, Caxias do Sul, Rio Grande do Sul, Brasil. Iheringia Série Botânica, v. 65, p. 75-86, 2012.

UEHLINGER, V. Étude statistique des méthodes de dénombrement planctonique. Archives des Science, v. 17, p. 121-233, 1964. https://dx.doi.org/10.1002/iroh.19650500319

UTHERMÖL, H. Zur Vervollkommnung der quantitativen Phytoplankton-Methodik. Mitteilungen Int Vereinigung Theor und Angew Limnology, v. 9, p. 1-38, 1958.

VAN den HOEK, C.; MANN, D. G.; JAHNS, H. M. Algae: an introduction to phycology. Cambridge: University Press, 2008.

VON SPERLING, M. Lagoas de Estabilização: Princípios do Tratamento Biológico de Águas Resíduárias. 2. ed. Belo Horizonte: UFMG, 2002. 196 p.

WHITTAKER, R. H. Evolution and Measurement of Species Diversity. Taxon, v. 21, p. $213-$ 251, 1972. https://dx.doi.org/10.2307/1218190

ZIMBA, P. V.; HUANGA, I-S.; GUTIERREZ, D. Euglenophycin is produced in at least six species of euglenoid algae and six of seven strains of Euglena sanguinea. Harmful Algae, 
v. 63, p. 79-84, 2017. https://dx.doi.org/10.1016/J.HAL.2017.01.010

ZORZAL-ALMEIDA, S.; BINI, L. M.; BICUDO, D. C. Beta diversity of diatoms is driven by environmental heterogeneity, spatial extent and productivity. Hydrobiologia, v. 800, p. 7-16, 2017. https://dx.doi.org/10.1007/s10750-017-3117-3 